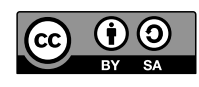

DOI: $10.4312 / \mathrm{mz} \cdot 57 \cdot 1 \cdot 177-200$

UDK 781.7(477):78.07(477)Ljudkijevič

\title{
Stanyslav Lyudkevych's Contribution to the History of Ukrainian Folk Music Research at the Beginning of the Twentieth Century
}

\author{
Oleg S. Smoliak, Anatoliy M. Bankovskyi, Oksana \\ Z. Dovhan, Halyna S. Misko, Natalia M. Ovod \\ Ternopil Volodymyr Hnatiuk National Pedagogical University, Ukraine
}

\begin{abstract}
The article explores and analyzes the activities of the famous Ukrainian composer, musical folklore collector and researcher Stanyslav Lyudkevych in the early twentieth century. The article presents an analysis of the ethnographic collection Halytsko-ruski narodni melodii (Galician-Rus Folk Melodies), which contributed to the emergence of a new direction in Ukrainian folk music ethnographic research - comparative musicology. In particular, this analysis explores structural and typological characteristics of Ukranian folk music.
\end{abstract}

Keywords: folk music research, Stanyslav Lyudkevych, ethnographic collection, rhythmic structure of the poem, song form and melodic rhythm

\section{IZVLEČEK}

Članek obravnava in analizira dejavnosti slavnega ukrajinskega skladatelja, zbiratelja glasbene folklore in raziskovalca Stanislava Ljudkijeviča v zgodnjem 20. stoletju. V članku je analizirana etnografska zbirka Halytsko-ruski narodni melodii (Galicijsko-ruske ljudske melodije), ki je $\mathrm{z}$ obravnavo strukturnih in tipoloških značilnosti ukrajinske ljudske glasbe prispevala $\mathrm{k}$ nastanku nove smeri na področju etnomuzikološkega raziskovanja - primerjalne muzikologije.

Ključne besede: raziskovanje ljudske glasbe, Stanislav Ljudkijevič, etnografska zbirka, ritmična struktura pesmi, oblika pesmi in melodični ritem 


\section{Introduction}

At the present stage of development of Ukrainian folk music research, the attention of researchers is drawn to the issues that are designed to comprehend and explore its main formation stages. This is primarily due to the fact that these issues are becoming increasingly important for their systematization. After all, Ukrainian musical folklore study of the early twentieth century created the foundations for the formation of a period of scientific research, which is a priority in its history to this day. This led to the application of new methods and the presentation of a number of ethnographers - Stanyslav Lyudkevych, Osyp Rozdolskyi, Filaret Kolessa, Volodymyr Hnatiuk, Volodymyr Shukhevych, Fedyr Vovk and others. These researchers formed a new school of Ukrainian folk music research, which was known almost throughout Europe in the early twentieth century. In particular, Stanyslav Lyudkevych and Filaret Kolessa developed the systematization of music folklore according to a new rhythmic-typological principle, which became the basis for the formation of a new scientific stage in its history, and introduced it into scientific practice.

At the beginning of the early twentieth century, Filaret Kolessa ${ }^{1}$ studied Ukrainian musical folklore. He selected and analyzed the examples of song folklore and classified them into ritual, historical, political and social songs. Filaret Kolessa saw the importance of folk songs primarily in the fact that they were close to people's lives and reflected the important events influencing their fate and changes in the social order.

Ivan Franko's ${ }^{2}$ scientific views were of great importance for the formation of the theoretical foundations of Ukrainian folk music research. He focused on poetics, Ukrainian songs rhythm as well as on integral studies of song folklore in their interrelation to history, literature and ethnography.

A significant contribution to the development of folk music research of the twentieth century was made by Klyment Kvitka ${ }^{3}$ and Lesya Ukrainka. ${ }^{4} \mathrm{Hav}-$ ing certain musical abilities and musical education, Lesya Ukrainka recorded folk songs with melodies. She recorded more than a hundred ritual songs with activities that accompanied certain genres - spring songs and children's

1 Filaret Kolessa, "Starynni melodii ukrainskykh obriadovykh pisen (vesilnykh i koliadok) na Zakarpatti," in F. M. Kolessa: Muzykoznavchi pratsi [“Ancient Melodies of Ukrainian Ritual Songs (Weddings and Carols) in Transcarpathia”] (Kyiv: Naukova dumka, 1970), 368-397.

2 Ivan Franko, Vybrani statti pro narodnu tvorchist [Selected Articles on Folk Art] (Kyiv: Vyd-vo Akademii nauk URSR, 1955).

3 Klyment Kvitka, Narodni melodii z holosu Lesi Ukrainky (Melodii z tekstom ta prymitkamy) [Folk Melodies from the Voice of Lesya Ukrainka (Melodies with Text and Notes)], written and arranged by [with foreword] Klyment Kvitka, vols. 1-2 (Kyiv: [Vydannia avtora], 1917-1918).

4 Lesya Ukrainka, Zapysy narodnoi tvorchosti: pisni, zapysani z holosu Lesi Ukrainky [Records of Folk Art: Songs Recorded from the Voice of Lesya Ukrainka] (Kyiv, 1977), 11-98. 
games. In 1902, Klyment Kvitka published Collection of Ukrainian Songs with Melodies ${ }^{5}$ harmonized by Borys Yanovskyi. It included ten songs with piano accompaniment.

Porfyrii Demutskyi ${ }^{6}$ did a lot of work on collecting and publishing folklore at the beginning of the twentieth century. He collected 253 songs, diverse in theme (love, history, social songs and songs about women's destiny, everyday content) and assembled them into Ukrainian Folk Songs in Kyiv Region collection.

Stanyslav Lyudkevych's ethnomusicological activity has attracted the attention of modern scholars as well. Thanks to the Ukrainian art critic Zenoviia Shtunder, ${ }^{7}$ a number of thorough works about Stanyslav Lyudkevych were published. In particular, a two-volume edition of the complete collection of music journalism by Stanyslav Lyudkevych was prepared. It covers the period from the end of the nineteenth century to the beginning of the 1970's. The collection contains articles on folklore, church music, music education and pedagogy, studies on music theory and the musical life of Western Ukraine, and reviews. The result of Zenoviia Shtunder's ${ }^{8}$ painstaking, long-lasting work is another monumental publication, which is a detailed chronicle of life and multifaceted activity of a composer, musicologist, folklorist, teacher, music expert and public figure.

Myroslav Antonovych's ${ }^{9}$ book paints a vivid portrait of the composer, enriched by the author's observations and impressions during his meetings with the composer in the early twentieth century. Essays on the life and work of the famous ethnomusicologist and composer were published by Ukrainian art critics Stefaniia Pavlyshyn ${ }^{10}$ and Mariia Zahaikevych. ${ }^{11}$

5 Klyment Kvitka, Zbirnyk ukrainskykh pisen z notamy [Collection of Ukrainian Songs with Melodies] (Kyiv, 1902).

6 Porfyrii Demuc'kij, Narodni ukrainski pisni v Kyjivshhyni zapysav golos i slova P. Demuc'kyj [Ukrainian Folk Songs in Kyiv Region Recorded the Voices and Words of P. Demutskyi] (Kiev: Gl. Sklad v kn. i muz. magazin Leona Idzikovskago, 1905).

7 Zenoviia Shtunder, Liudkevych S.: Doslidzhennia, statti, retsenzii, vystupy [Lyudkevych S.: Research, Articles, Reviews, Speeches], vols. 1-2 (Lviv: Dyvosvit, 1999-2000).

8 Zenoviia Shtunder, Stanislav Liudkevych: Zhyttia i tvorchist, T. 1 (1879-1939) [Stanyslav Lyudkevych: Life and Work; vol. 1 (1879-1939)] (Lviv: BINAR-2000, 2005); and Stanislav Liudkevych: Zhyttia i tvorchist, vol. 2 (1939-1979) [Stanyslav Lyudkevych: Life and Work; vol. 2 (1939-1979)] (Lviv-Zhovkva: Misioner, 2009).

9 Myroslav Antonovych, Stanislav Liudkevych: kompozytor, muzykoloh [Stanyslav Lyudkevych: Composer, Musicologist] (Lviv: Veritas, 2007).

10 Stefaniia Pavlyshyn, Stanislav Liudkerych [Stanyslav Lyudkerych] (Kyiv: Muzychna Ukraina, 1974).

11 Mariia Zahaikevych, S. P. Liudkevych: Narys pro zhyttia i tvorchist [Stanyslav Ludkevych: Essay on Life and Work] (Kyiv: Derzhavne vydavnytstvo obrazotvorchoho mystetstva i muzychnoi literatury URSR, 1957). 
In his works, the musicologist Bohdan Lukaniuk ${ }^{12}$ considers Stanyslav Lyudkevych's cultural and genre concept as well as the history of typological school in Ukrainian ethnomusicology and analyzes the contribution of Stanyslav Lyudkevych as its founder.

\section{Stanyslav Lyudkevych and Osyp Rozdolskyi's Collection Galician-Rus Folk Melodies - the Beginning of Scientific Folk Music Research}

There are few artists in the European music history whose creative activity combines the interests of a composer, collector and researcher of folklore, yet this phenomenon is typical for Eastern European music and young schools of composition of the nineteenth and twentieth centuries because their formation and development coincide with the growing interest in folk art around the world as well as awareness of its great importance for the development of human culture under the influence of the aesthetics of the new era. Today it is difficult to even imagine how the canons of the Classicism were applied simultaneously with the sound of works by such composers as Johann Sebastian Bach, Joseph Haydn, Dmytro Bortnianskyi and Maxym Berezovskyi, filled with healing sources of folklore; despite the fact that in the Classicism, canonical works considered for high aristocratic taste were in opposition to common people's taste.

The increasingly open protest resulted in literature and art of revolutionary Romanticism, the main feature of which was an active appeal to the folk art treasures. Such tendencies marked the activity of Mykhailo Glinka and the composers of "the Mighty Five" in Russia; Bedřich Smetana, Antonín Dvořak, Leoš Janáček in the Czech Republic; Stanisław Moniuszko, Frédéric Chopin, Karol Szymanowski in Poland; and the young Hungarian school with Béla Bartók and Zoltán Kodály; Norwegian and Finnish composers Edward Grieg and Jean Sibelius; Ukrainians Mykola Lysenko, Petro Sokalskyi, Mykola Leontovych, Kyrylo Stetsenko and their younger followers, and made a great contribution to the preservation and study of folklore heritage. Stanyslav Lyudkevych was no exception. He very early showed interest in folk music. It is noteworthy that his first and widely known folklore-based work Galician-Rus Folk Melodies $(1906,1908)$ was published just a year after his first outstanding musical work, The Caucasus (1905), after which he was considered a prominent Ukrainian composer.

12 Bohdan Lukaniuk, "Kulturo-zhanrova kontseptsiia S. Liudkevycha," in Chetverta konferentsiia doslidnykiv narodnoi muzyky chervonoruskykh (halytsko-volodymyrskykb) ta sumizhnykh zemel: Materialy ["Cultural-genre Concept of S. Lyudkevych"] (Lviv, 1993), 7-14; Bohdan Lukaniuk, "Stanislav Liudkevych yak zachynatel typolohichnoi shkoly v ukrainskomu etnomuzykoznavstvi," in Zbirnyk statei i materialiv v pamiat Yaremy Yakubiaka (1942-2002) ["Stanislav Lyudkevych as the Founder of the Typological School in Ukrainian Ethnomusicology"], compiled by M. Kushnir (Lviv: Kameniar, 2007), 140-161. 
Despite his interest in folk music, Stanyslav Lyudkevych did not consider ethnography and stylization - rather, he searched for ways how to include folk in his own artistic work. The same words that Stanyslav Lyudkevych said about Ivan Franko describe him as a folklorist: "he was alien to the views of some aesthetes who saw primitive exotics in Ukrainian folk music and song."13 The same thoughtful philosophical take on folk heritage was felt in his lectures on folk music, which he gave to students of the Lviv Musical Academy: short concise comments on folk songs captured a deep understanding of their essence, language and significance for the cultural history.

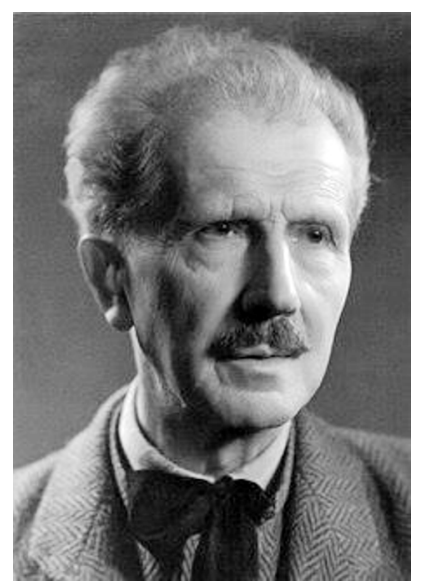

Figure 1: Stanyslav Lyudkevych in the late 1960's.

The collection Galician-Rus Folk Melodies became an important part of Ukrainian folklore science and paved the way for comparative musicology. In European science, this trend began to take shape in the late nineteenth and early twentieth centuries under the influence of new research in folk music and ethnography. The use of a phonograph considerably accelerated and facilitated the process of collecting musical materials and their musical interpretation, and thus contributed significantly to musical science. From quantitative accumulations of samples, it was possible to focus on their qualitative comprehension, development of principles of the scientific analysis and classification. With the collection Galician-Rus Folk Melodies, Stanyslav Lyudkevych and his co-author Osyp Rozdolskyi ${ }^{14}$ were the pioneers of the application of

13 Stanyslav Lyudkevych, "Muzyka sertsia," in Ivan Franko u spohadakh suchasnykiv ["Music of the heart”], book 2, ordering, preface and notes O. Deia (Lviv: Kameniar, 1972), 176.

14 Osyp Rozdolskyi, a collector and researcher of Ukrainian folk music, recorded/collected 3.000 folk songs with melodies in 1900-1936, and collaborated with Stanyslav Lyudkevych, Volodymyr Hnatyuk and Filaret Kolessa, whom he met while studying at Lviv University. Records of Ukrainian songs, fairy tales and legends represent the largest part of Osyp Rozdolskyi's works. In April 
phonograph recordings and their transcriptions in Ukrainian folklore science. Stanyslav Lyudkevych worked on transcribing songs and systematizing them for four years - from 1902 to 1906.

In the introductory article to the collection, Stanyslav Lyudkevych wrote about his co-author with great fondness:

I want to note that Dr. Rozdolskyi, endowed with an exceptional memory and a fine understanding of folk songs, was well acquainted with the collected material and presented different genres of songs so that almost nothing had to be thrown away. ${ }^{15}$

Ivan Franko called Osyp Rozdolskyi an extremely vigilant and diligent collector. ${ }^{16}$ On November 22, 1906, at a meeting of the philological section of Shevchenko Scientific Society, he analyzed the work of Stanyslav Lyudkevych and Osyp Rozdolskyi, gave it a high assessment and recommended it for publication. ${ }^{17}$

Thanks to a large number of recordings collected by Osyp Rozdolskyi, the collection of Stanyslav Lyudkevych and Osyp Rozdolskyi includes 1.525 melodies recorded on the territory from the lands above the Zbruch river to the western Carpathians. The work became a valuable addition to the folklore collections of Mykola Lysenko collected in the central-eastern and partly western lands of Ukraine. As it can be seen from the register of villages and counties where the material was collected, the collection covers most melodies from the northern and central areas of Galician Podillya (Ternopil, Zbarazh, Sokal, Przemysl), Carpathian foothills (Sambir, Stryi, Dobromil, Turka) and some mountain villages (Mykulychyn, Nadvirna), separate districts of Pokuttya (Sniatyn region) and Lemkiv region. The collection was distinguished by its innovations in the presentation of material. Unlike previous folklore editions, arranged by texts, Stanyslav Lyudkevych focused on the melody. $\mathrm{He}$ wrote about the arrangement of songs by lyrics:

It is easy to understand, that such a task of division in practice is often superficial and one-sided, because when the basis of division should be the typicality of the song, then it is equally superimposed with text and melodic form. ${ }^{18}$

1900, Osyp Rozdolskyi used a phonograph for the first time in Galicia to record folk melodies and became the first to use sound recording techniques for documenting folk melodies in Central and Eastern Europe.

15 Halytsko-ruski narodni melodii, Zibrav na fonohraf Y. Rozdolskyi, spysav i zredahuvav S. Liudkevych, [Galician-Rus folk melodies, collected with a phonograph by O. Rozdolskyi, written and edited by S. Lyudkevych], Etnohrafichnyi zbirnyk Naukovoho tovarystva im. Shevchenka, vol. 21, (Lviv, 1906), 5.

16 Ivan Franko, Vybrani statti pro narodnu tvorchist [Selected Articles on Folk Art] (Kyiv: Vyd-vo Akademii nauk URSR, 1955), 242.

17 Shtunder, Liudkevych S.: Doslidzhennia, statti, retsenzii, vystupy, 13.

18 Halytsko-ruski narodni melodii, vol. 1, 6. 


\section{ЕТНОРРАФФНИЙ ЗВРНИИК.}

ВIДАG ВТНОI'РАФІЧНА НОМІС̈Я

НАУКОВОГО ТОВАРИСТВА ГМЕНИ ШЕВЧЕНКА.

T. $\mathbf{X X 1}$.

ГАЛИЦЬКО-РУСБЕІ НАРОДНІ МЕЛЬОДІЇ

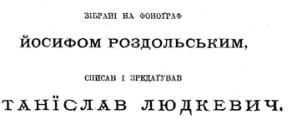

ЧАСТЬ I.

y ЛЬВОВI, 1906.

Накладом Наукового Товариства імени Шевченка.

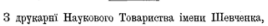

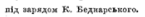

Figure 2: The title page of the collection Galician-Rus Folk Melodies by S. Lyudkevych and O. Rozdolskyi, 1906, vol. 1.

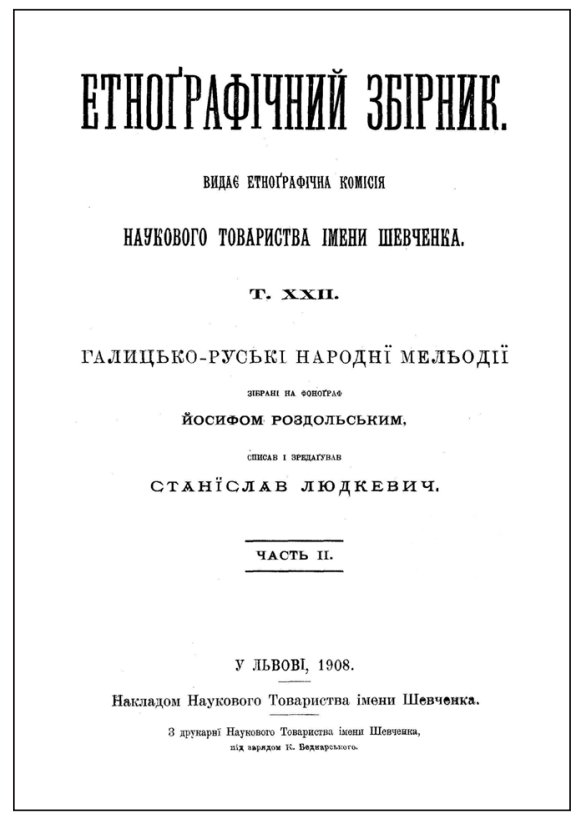

Figure 3: The title page of the collection Galician-Rus Folk Melodies by S. Lyudkevych and O. Rozdolskyi, 1908, vol. 2.

Stanyslav Lyudkevych systematized the material of the collection by genres, placing the main emphasis on grouping songs by rhythmic types of verse and stanza.

The principle of classification of songs by their textual rhythmic and structural features was, at that time, relevant in the folklore science of many countries. Suffice it to recall the rhythmic classification of songs proposed by the Finnish scholar Julius Krohn, who had a wide resonance in folklore. ${ }^{19}$ In Ukraine, the doctrine of the folk songs rhythm had its own tradition, supported by the works of Olexandr Potebnia ${ }^{20}$ and Petro Sokalskyi. ${ }^{21}$

19 Abstract entitled "Welche ist die beste Methode um Volks- und volksmässige Lieder nach ihrer musikalischen (nicht textlichen) Beschaffenheit lexikalisch zu ordnen," Sammelbände der Internationalen Musikwissenschaft, vol. IV, pp. 643-646 was published in response to D. Scheiler's competition question under a similar title, i.e. "What is the best system for arranging folk songs according to their melodic (not textual) nature?"

20 Olexandr Potebnia, Poiasnennia malorosiiskykh i sporidnenykh narodnykh pisen: Koliadky ta shchedrivky [Explanation of Little Russian and Related Folk Songs: Carols and Shchedrivkas], vol. 2 (Warshaw: Drukarnia Mykhaila Zemkevicha, 1887).

21 Petro Sokalskyi, Ruska narodna muzyka: rosiiska i ukrainska v yii budovi melodychnii i rytmichnii vidminnosti yii vid osnov suchasnoi harmonichnoi muzyky [RUS Folk Music: Russian and Ukrainian in its Melodic Structure and Rhythmic Difference from the Foundations of Modern Harmonic Music] (Kyiv: Derzhavne vydavnytstvo obrazotvorchoho mystetstva i muzychnoi literatury URSR, 1959). 
In 1905, Filaret Kolessa completed his fundamental study Rhythmics of Ukrainian Folk Songs, which, after a positive review by Ivan Franko in 1906, was published in the Shevchenko Scientific Society Notes. The central sections of the work described the doctrine of the musical-syntactic foot ("song knee") and the classification of song stanzas types according to their rhythmic features. This concept of organizing folklore became the leading one in the folk songs publications of this society. As Stanyslav Lyudkevych wrote in the introduction to the collection Galician-Rus Folk Melodies, he did not immediately opt for the rhythmic principle.

At first, at the very beginning of my work, I decided to arrange the songs on a melodic system basis, starting from two-tone songs and moving on to those by which scale turned into a fourth, fifth, octave, and so on. This led me to the idea of the melody emergence based on the music scale expansion, but while working, I made sure that such an arrangement would cause a mismatch of song forms because while the music scale was often something random, the creation and transformation of forms was much more distinct against the rhythmic element background than exclusively in the tonal structure. ${ }^{22}$

The collection, consisting of two parts, is divided into four main groups:

A. Ritual songs (nos. 1-216):

- harvest songs,

- wedding songs,

- Christmas carols (kolyadky) and New Year's Eve carols (shchedrivky),

- spring (ritual) songs (vesnianky and hayivky).

B. Household songs (nos. 217-1018):

- ballads,

- love songs,

- family songs,

- lullabies.

C. Dance songs and songs of similar type (nos. 1019-1300):

- kolomyiky, ${ }^{23}$

- similar to kolomyiky,

- related to dance songs.

D. Borrowed songs (nos. 1301-1415):

- religious (grandfatherly),

- songs of written origin,

- songs of Polish folk origin.

23 Kolomyiky is a traditional genre of Ukrainian folk music and choreography. It is a two-line folk song, each line of which has 14 syllables with obligatory caesura after the eighth syllable. Kolomyiky is also an expression for short songs that can act as refrains to dance. 
"Lemko Songs" (nos. 1416-1506) and "Appendix" (nos. 1507-1525) are separately presented at the end of the second part of the collection.

Within the framework of the named genres, the systematization of songs by types of verse and stanza was carried out. In the group of household songs, songs are divided into "homogeneous" (today they are called "isosyllabic"; like $4+4,5+5$ ) and "heterogeneous" (for example, $6+4,5+3$ ) or heterosyllabic. The classification of songs according to the rhythmic features of the poem and the song stanza provides valuable material for studying the compositional features of Ukrainian folk song, the typology of connections between certain constructions of poem and melody. Considering the stanza with verse $4+6$ typical for Ukrainian song, we have a small anthology of possible variants of rhythmic interpretation in the melody of this verse type, we see narrative types in which it most often occurs, we observe the combinations of repetitions, refrains that are inherent to this rhythmic type. Unconditionally, the stanza with verse $4+6$ is most commonly used in ballads and long lyrical songs. The rhythmically extended ending of the melody harmonizes with the semantic emphasis at the end of the sentences. It is also extended due to the repetition of the second "song knee": $4+$ [: 6:] or the second syntagm: $4+6$ [: $4+6:]$. Possible rhythmic interpretations of individual "song knees" in the melody are also taken into account.

Ivan Franko rightly noted that typical melodies with their variants embody to the greatest extent everything that was created or mastered in the musical direction by the Ukrainian people. ${ }^{24}$

Subtly feeling the rhythmic and melodic nuances of the folk song, Stanyslav Lyudkevych gave instructions on their rhythmic modeling in analytical schemes at the beginning of each group; these are used in scientific literature up to this day. The examples of mirror combinations in the stanza, the ratio of the main text and refrains, combinations of verse groups and their embodiment in the melody make for some quite interesting reading in the book.

For the same reasons of typology, the collection contains as many variants of each song and types of stanza as possible, which enables tracing the morphological variability of each sample of the song. The significance of the rhythmic concept and principles of melodic typology was not immediately appreciated in science. Thus, Klyment Kvitka wrote in the article "Modern Ukrainian Musical Ethnography" under the pseudonym "Tymysh Boreyko" about the collection of Stanyslav Lyudkevych and Osyp Rozdolskyi:

The biggest sign of asceticism in Lyudkerych's work is that he largely voluntarily made his work dry and cheerless for himself, namely because of the accepted classification of the 
material... That is why we have long boring lines of colorless versions of colorless melodies among the most interesting songs in Lyudkerych's collection. ${ }^{25}$

Over time Klyment Kvitka's views have changed radically as evident from his meticulous explorations of the folk melodies rhythm and his own confessions. In the letter to Filaret Kolessa dated June 11,1923, about his collection Ukrainian Folk Melodies (1922), Klyment Kvitka wrote: "I am very sorry for the fact that I did not follow the rhythmic systematization in ordering melodies and, printing them, I was sure that their analysis would be printed as well." ${ }^{26}$

In the same letter, he praised the article "Rhythmics of Ukrainian Folk Songs" by Filaret Kolessa, in which the scientist classified song forms based on the doctrine of rhythmic and syntactic "foot" developed by him. ${ }^{27} \mathrm{He}$ showed solidarity with the rhythmic and structural studies of songs in the folklore editions of Shevchenko Scientific Society, where Stanyslav Lyudkevych also published his articles.

Thus, the collection Galician-Rus Folk Melodies by Stanyslav Lyudkevych and Osyp Rozdolskyi became a milestone in the history of Ukrainian folk music research - it started a new scientific stage. The introductory article by the collector and editor Stanyslav Lyudkevych turned out to be innovative from the methodic and methodological points of view because for the first time, the phonographic way of documenting folklore material was pointed out and ways to improve it in the future were outlined.

\section{Structural and Typological Characteristics of Stanyslav Lyudkevych and Osyp Rozdolsky's Collection - Galician-Rus Folk Melodies}

With the deepening of analytical research of narrated and musical folklore, new knowledge of its morphology and syntax, the value of records available in the arsenal of folklore science was constantly reassessed. Thus, the realization of specific incompatibilities between the Western European music time system and the rhythm of Eastern European song, which affected its notation, did not come immediately but only after the structure of song texts and melodies of Russian, Ukrainian and Belarusian songs was analyzed and their inherent principles were found. Notation in music is a kind of classification grid that determines the sound material and it is more natural the more it corresponds to the sound source. However, it is largely subject to the recorder's auditory perception, his musical talents and his sense of the material.

Tymish Boreyko [Klyment Kvitka], "Narodni spivtsi-profesionaly" ["Folk Singers-Professionals"], Ridnyi krai 15 (1912): 15.

26 Filaret Kolessa, "Rytmika ukrainskykh narodnykh pisen" ["Rhythmics of Ukrainian Folk Songs"], in F. M. Kolessa: Muzykoznavchi pratsi (Kyiv: Naukova dumka, 1970), 175. 
It is not coincidence that Stanyslav Lyudkevych paid attention to the issue of folk song notation in the introduction to the collection Galician-Rus Folk Melodies, calling it a "stumbling block" for recorders. Lyudkevych characterized both rhythmic and pitch ways of music notation. As Stanyslav Lyudkevych noted:

It is almost impossible to transfer a folk song correctly and accurately to sheet music, it has many features in its melodic and rhythmic features that do not quite correspond to modern musical patterns, so by the very recording of the song in our music system, we erase its characteristic features, change its "face." 28

In this regard, Stanyslav Lyudkevych raised the question of whether to divide Ukrainian folk songs into musical measures or to transcribe them without time, with a division into periods after the caesura of the text. The composer chose another principle. He gave the reader the freedom to count the rhythmic units between the lines. But if we can agree with this principle about songs like parlando with their free rhythmic construction of improvisational character, many of which are among wedding ritual songs, and lyrical epic recitatives, which are really difficult to put in a fixed scheme, then the tactless transcribing is not justified for songs like giusto, where the univariate rhythmic division is quite clear.

It is also necessary to emphasize Lyudkevych's subtle feeling of the rhythmic song structure and its natural caesura. So, for example, singing epic songs with a kolomyika verse (the compiler placed them at the beginning of the II part of the collection), are shown mainly with two (4/4/6), and even one caesura (8/6), as they are sung by people - in a free parlando style (see nos. 739 and 748 etc.). In the dance kolomyikas, each fourteen-syllable syntagm is divided into three caesuras as required by the rhythm of the melody.

739.
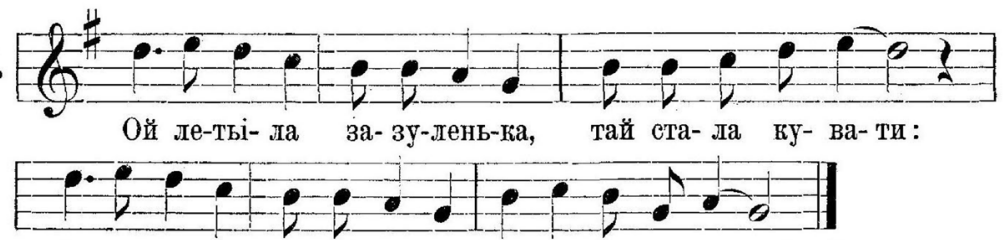

за- чи- кай-те до- брі льу-ди штось ма-йу ка- за-ти! Волчуси.

$$
(8+6)+\left(8^{\prime}+6^{\prime}\right) \text {. }
$$

Figure 4: Song with a kolomyika verse with two caesuras. 


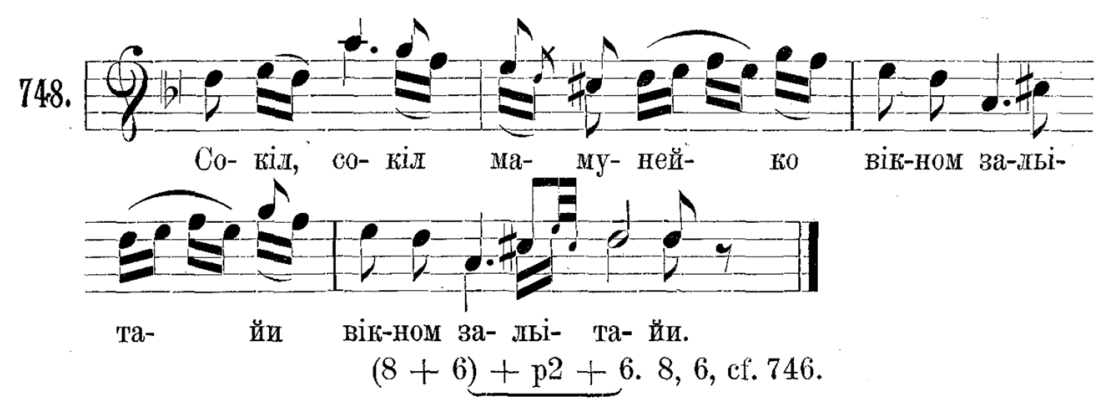

Figure 5: Song with a kolomyika verse with one caesura.

In the introductory article, the compiler also drew attention to the notation of the intonation-system structure of folk songs. He recommended starting from the tone scale that actually appears in the folk song and, accordingly, to put down key signs. Stanyslav Lyudkevych also defended the accurate record of the tempo and absolute pitch of the song in which it was performed by the singer.

Correct recording of the absolute pitch of sung melodies can be a good indicator of the voice register of our people. A detailed definition of the tempo is important because that the concept of tempo usually includes a definition of the nature of the song. ${ }^{29}$

But none of these conditions could be met by the researcher due to the imperfection of the first phonographic recordings, the sound of which was not accurate in terms of tempo and pitch. Therefore, the decodings are reduced mainly to the pitch level with the reference tone g, and the tempo is not fixed. The value of both indicators for the scientific records is increasingly obvious in the light of the doctrine of the rhythmic sphere of time ${ }^{30}$ and pitch analysis of the melody's microelements. As Stanyslav Lyudkevych wrote, another point that stands in the way of detailed/comprehensive recording is that folk singers perform the song in an untempered tone system, while the Ukrainian music system knows only the tempered scale. ${ }^{31}$ The researcher rightly noted that these discrepancies are manifested primarily in the intervals of the fourths in minor scales, where they are heard as pure or as enlarged, in the unstable third, which is called "neutral" in many later folklore works. ${ }^{32} \mathrm{He}$ interprets moments

29 Ibid., 9.

30 Polish researcher Ludwik Bielawski also confirms the opinion of S. Lyudkevych in his work Strefowa teoria czasu. Ludwik Bielawski, Strefowa teoria czasu (Krakow: Polskie Wydawnictwo Muzyczne, 1976), 29.

31 Halytsko-ruski narodni melodii, vol. 1, 10.

32 Erich Moritz Hornbostel, "Die Probleme der Vergleichenden Musikwissenschaft," Zeitschrift der Internationalen Musikgesellschaft 7 (1905): 92-93. 
of natural intonation as a phenomenon typical to many peoples of the world, referring, in particular, to similar observations by the Austrian researcher Richard Wallaschek about the same thirds and quarts in Tasmanian music. ${ }^{33}$

Stanyslav Lyudkevych's views on this issue are somewhat contradictory. He discussed this topic also in the article "A Few Notes on the So-Called Fractions in Our Folk Songs" where he called such deviations a matter not worth paying attention to, or even a "fantastic fabrication" because "the ear of any (not only "natural") singer instinctively adheres to natural intervals and only with difficulty distinguishes too small differences in intervals, the socalled coma, and greater or lesser sensitivity of the ear depends on individual hearing," and differences in intonation cannot be more than the usual fault. ${ }^{34}$ New acoustic equipment and experimental studies of the natural melodic system and the revealed regularities of "dualism" of intervals show that such deviations in "folk intonation" are quite significant and allow to adhere, for example, in Ukrainian folk music not to a 12-degree scale, as it was thought for a long time, but to a 22-degree scale..$^{35}$ However, the method of intonation is not the same in all geographical zones of Ukraine. In some, it is closer to "untempered," in others - to tempered, but deviations are in most cases not perceived as fault but as a consequence of the variation specifics of intonation. In the introduction to Galician-Rus Folk Melodies, the researcher himself rightly noted:

To navigate in these nuances and to distinguish real and imaginary "fault" in singing, you need only extensive experience and detailed acquaintance with the songs themselves in many versions and different manners of the singer. ${ }^{36}$

He already noted these faults in the collection of Lemko songs by Filaret Kolessa. ${ }^{37}$ Modern folk music research distinguishes them by various conventional symbols.

Stanyslav Lyudkevych's interesting remarks concerned the melody style of Western Ukrainian folk songs, in which he saw dialectal differences, which consisted primarily in certain types of melismata and their relation to text rhythm. The researcher clearly distinguishes between the concepts of the text and melodic rhythm, understanding that it is the melodic rhythm that outlines the dialectal specificity of the melody.

Richard Wallaschek, Anfänge der Tonkunst (Leipzig: J. A. Barth, 1903): 165-166.

Shtunder, Liudkevych S.: Doslidzhennia, statti, retsenzii, vystupy, 307.

Polykarp Baranovskyi and Evgen Yutsevych, Zvukovysotnyj analiz svobodnogo melodicheskogo stroja [Sound-Pitch Analysis of Free Melodic Structure] (Kiev: Izdatel'stvo Akademii nauk URSR, 1956), 4.

36 Halytsko-ruski narodni melodii, vol. 1, 7.

37 Kolessa, "Rytmika ukrainskykh narodnykh pisen," 179. 
Wonderful melodies of Ukrainian songs from the Dnieper region are in comparison with some truly monotonous Galician completely modern and gradual, which, despite all their original features, are closer to Western European (Italian) music culture and inherited from it much more than our Galician. ${ }^{38}$

In the book, Stanyslav Lyudkevych dedicated a special place to ethnocultural interactions in folklore. In his opinion, Western Ukrainian song was mostly influenced by Poland, in particular in the villages of Galician Podillya and in the foothills, while the Slovak-Hungarian influence is too obvious in the rhythmic and melodic features of Lemko songs. ${ }^{39}$

Thus, the principles of systematization and classification of musical folklore in the collection Galician-Rus Folk Melodies by Stanyslav Lyudkevych and Osyp Rozdolskyi turned out to be an innovation in the early twentieth century because they were the first to give guidelines for a scientific approach to the collected musical and folklore material. The structural-typological principle of classification appeared to be quite effective and scientifically substantiated. It provided an opportunity to understand the nature of the structure of folk songs and their multifaceted origins. What is more, it outlined the ways for the future phonography of collected folklore materials and brought Ukrainian musical folklore to a high European level.

\section{Cultural and Genre Systematization of Stanyslav Lyudkevych's Song Material}

In 1906, Stanislav Lyudkevych completed preparations for the publication of the collection Galician-Rus Folk Melodies - an important ethnomusicological work, which not only immediately positioned Ukrainian folk music research among the leading in the Slavic world but also, being absolutely innovative in almost all respects, initiated a methodologically completely new typological direction. In particular, Stanyslav Lyudkevych applied at the time in the world literature unprecedented principles of systematization of folk songs in this collection.

Stanyslav Lyudkevych rightly identified the need for a radical revision of the principles of grouping and ordering of folk songs as the widely used thematic or genre-and-thematic systematizations were full of fundamental errors:

All previous collections of Slavic folk songs with melodies, arranged from the oldest to the newest, present melodies as an appendix to the lyrics and place the material after the text, but it is easy to understand that such a division of songs is often superficial and one-sided because the basis of the division should be the song types as a song equally consists of lyrics and melodic form, which are its two inseparable elements. ${ }^{40}$

39 Ibid., 15-16.

40 Ibid., 10. 
Indeed, if philological folklore primarily studies the topics (plots, motives) of oral literature with different thematic or genre-thematic classifications which, despite their obvious logical inability, ${ }^{41}$ are natural and generally productive, then in folk music research such classifications could also make sense if the outlined themes more or less strictly corresponded to melodies of a certain type or at least figurative composition, which would be unambiguously different from melodic types with other themes. In other words, the relationship between the musical and lyrics components of a folk song should be fairly stable, but the folklore reality shows a completely different pattern.

For example, respectful ritual texts of wedding songs during the rite of the bridecake, wreath-making or farewell to the bride, belong to the same "group melody" 42 and generally to the same performance manner (i.e. without any noticeable changes). The same goes for sharp satirical jokes about a cook, a warden, and boyars (friends) in non-ritual songs which seem more individualized figuratively and structurally - they have a tragic ballad plot completely interlaced with a fun-carefree and even bravura-marching melody. ${ }^{43}$

Similar examples are common, because in folk songs, in general, the same melody is used for completely different texts topics - historical, social, love, ballads or sometimes even lullabies. The same applies to kolomyika (song, chorus song), where the same melody is often used in several thousand stanzas of various contents; and vice versa - exactly the same texts are freely combined with completely different melodies, which have been repeatedly noted by Ukrainian and foreign scholars.

In both Ukrainian and Eastern European songwriting in general, the history of melody creation rarely coincides with the history of lyrics creation they are quite freely combined in the process of creation and oral distribution, and, therefore, to study the musical typology of any grouping of folk songs in practice does not provide the exact definition of a genre and actually avoids its direct task dividing usually close, variant-related melodies and uniting absolutely distant and alien.

Accordingly, Stanyslav Lyudkevych, dealing with melodic material, decided to organize a collection of typical music forms of folk songs and to analyze the recorded material. First of all, he singled out songs that, in terms of content, form, origin and circumstances in which they are sung, form distinct typical groups that were clearly distinguished from others. Such groups included:

41 All genre-thematic classifications of folk songs violate the basic conditions of the correct division of generic concepts into species, namely the rules of unity of the divisional basis (signs or groups of signs), its exhaustiveness and continuity, incompatibility of selected classification units-members of the division.

42 Filaret Kolessa coined this term and it became widespread after writing the paper: Kolessa, "Starynni melodii ukrainskykh obriadovykh pisen (vesilnykh i koliadok) na Zakarpatti."

43 Klyment Kvitka, "Ukrainskie pesni o materi-detoubijce" ["Rhythmics of Ukrainian folk songs"], in Kvitka K.: Izbrannye trudy v dvuh tomah, vol. 2 (Moskva: Soviet kompozitor, 1973), 169-174. 
ritual songs (wedding songs, harvest songs, carols, Christmas carols, springtime songs i.e. - vesnyanki and gaivky), dance songs, related, as well as borrowed songs of foreign origin. Thus, a group of songs stood out in number more than all the others in the collection, among which it was difficult to find clear typical differences both in content and form. These songs were called household songs. There are double songs, where only formal signs could reveal their belonging to a particular song genre. At the same time, Stanyslav Lyudkevych took two of its most characteristic features as the basis for determining the song form - the rhythmic structure of the text and the schematic rhythmic pattern of the melody, which in some cases are supplemented by the peculiarities of the tonal structure. ${ }^{44}$

In this way, Stanyslav Lyudkevych solved the task he had taken on - to find as many features as possible which were necessary to define a certain type in full accordance with the nature of folk song. He fundamentally rejected the errors in nature but then commonly used the genus-species division by subject. He put forward his own, purely ethnomusicological concept of grouping folk melodies by song types, which are determined not only by the formal features of the verse and musical-rhythm melodic structure influenced by culture and genre, but also origin and circumstances in which they are sung (i.e. on what occasion).

In the first decade of the twentieth century, the question of developing an effective method of classifying songs not by text but by musical characteristics arose in European ethnomusicology. The competition, organized by the International Music Society in 1907, received four proposals, but only two were recognized worthy of publication: "Methods of Cataloging Linear Incipits" by the Austrian scientist Oswald Köller and "Methods of Lexical Ordering of Songs" by the Finnish scientist Julius Krohn. The method of the latter actually became dominant in the first half of the twentieth century, making a certain impression even on the representatives of Ukrainian folklore science, in particular on Filaret Kolessa and Volodymyr Hoshovskyi.

With the publication of the collection Halytsko-ruski narodni melodii (Galician-Rus Folk Melodies), Stanyslav Lyudkevych seemed to respond to the competition question of the International Music Society: "What is the best method of arranging folk and related songs according to their musical (nonlyrics) properties?" This was, in fact, the second attempt of a typological systematization on a European scale and it was not only more successful than the famous Krohn's (suitable only for a limited range of four-phrase melodies), but certainly surpassed it in all respects - since it was universal and sufficient in details and rationality, it was inherently flexible and realistic, and could adapt to the specifics of particular folk material. 
However, surprisingly, Stanyslav Lyudkevych's collection, despite the current European requirements, did not make a proper impression on contemporaries. He was met with the opposition of his more conservative colleagues rather than recognition. As far as we know, none of the contemporary folk musicians in Galicia or abroad in the east or west responded directly to the publishing of the collection Galician-Rus Folk Melodies, which immediately took a prominent place in Eastern European musical and ethnographic literature. However, four years later he was severely criticized by Klyment Kvitka, who later published his own collection of Folk Melodies, arranged quite traditionally based on the theme of poetic texts. ${ }^{45}$ However, later he decisively changed his views in favor of Stanyslav Lyudkevych.

With the Soviet Union occupying the western Ukrainian lands, the systematization of Stanyslav Lyudkevych was unequivocally classified as formalistic with its subsequent non-recognition. And if some ethnomusicologists mentioned it in occasional reviews, at best, it was only briefly described without the slightest attempt of analytical reasoning or a critical approach. Although this critique did not bring anything new, it was only the subject of discussion in regard to the expediency of the very principle of arranging folk songs based on rhythmic, and at the genre level, no one tried to analyze it.

Stanyslav Lyudkevych's cultural-genre systematization was an epoch-making methodological breakthrough in Ukrainian folk music research. And even if the systematizing ideas of Stanyslav Lyudkevych had not gained wide publicity and practical application at this time, they still would have waited for a proper critical assessment because today they are considered methodologically most correct. Therefore, Stanyslav Lyudkevych's genre systematization, which first acquired practical application in the collection Galician-Rus Folk Melodies, made him the most significant figure in the history of Ukrainian folk music research.

\section{Conclusions}

Representatives of Ukrainian folk music research at the beginning of the twentieth century achieved significant success in collecting folklore materials of various genres - ritual, household, epic, instrumental art. During this time, thorough research and collections appeared. Among them are Filaret Kolessa's "Rhythmics of Ukrainian Folk Songs" and "Melodies of Ukrainian Folk Dumas," a collection in two parts Galician-Rus Folk Melodies by Stanyslav Lyudkevych and Osyp Rozdolskyi, "Folk Melodies from the Voice of Lesya Ukrainka" by Klyment Kvitka and several other valuable works. These works formed the principles of a historical and typological approach in the study of musical folklore, its structural analysis, classification. The discussed principles 
were in concord with the best achievements of European musicology and they have not lost their relevance for modern science.

Despite the occasional excessive fascination with the formal song features, Ukrainian scholars did not separate it from the historical ground nor formed a clear functional-genre concept of folklore. With such developments, Ukrainian musical folklore gained a strong position in the system of (Eastern) European ethnomusicological science in general and the Ukrainian song creation aroused a keen interest in prominent researchers from other countries. The activity of Stanyslav Lyudkevych, Filaret Kolessa, Klyment Kvitka, Porfyrii Demutskyi and Hnat Khotkevych became a strong bridge that connected East Ukrainian and West Ukrainian folklore schools.

The weight and significance of Stanyslav Lyudkevych's works are best appreciated in modern practice. The problems of folklore classification, which were in the key aspect of his works, have become the center of modern research. They find further development and deepening in the light of new challenges in modern science.

Studying the ethnomusicological heritage of Stanyslav Lyudkevych, one cannot help but be surprised that at the age of twenty-four, the composer already reached the heights of Ukrainian musicology, which are unsurpassed even today. These heights include a cultural-genre systematization of folklore, which has made revolutionary changes in the genre-generic approach, in particular regarding its rejection of generic features in folklore. This approach made it possible to classify Ukrainian folklore in a new way. Stanyslav Lyudkevych significantly expanded the concept of modern folklore and its functions in the development of professional art. He showed the enormous potential of the artistic transference of the concept into practice. As a thoughtful and observant musician, he contributed to its preservation, systematization and scientific understanding. As a true scientist and a man of progressive views, Stanyslav Lyudkevych demonstrated the great social role of folklore in the development of consciousness and enrichment of the culture of all mankind.

Stanyslav Lyudkevych's works became the basis in folklore scientific circles, which is relevant today because his analytical approaches are extremely deep and culturally determined. His works will always be a guide not only for Ukrainian but also for foreign scientists.

\section{Bibliography}

Antonovych, Myroslav. Stanislav Liudkevych: kompozytor, muzykoloh. [Stanyslav Lyudkevych: Composer, Musicologist.] Lviv: Veritas, 2007. [Антонович, Мирослав. Станіслав Людкевич: композитор, музиколог. Львів: Veritas, 2007.]

Baranovskij, Polikarp, and Evgenij Jucevich. Zvukovysotnyj analiz svobodnogo melodicheskogo stroja. [Sound-pitch Analysis of Free Melodic Structure.] Kiev: Izdatel'stvo Akademii nauk URSR, 1956. [Барановский, Поликарп, Евгений Е. Юцевич. Звуковысотнылй 
анализ свободного мелодического строя. Киев: Издательство Академии наук УРСР, 1956.]

Bielawski, Ludwik. Strefowa teoria czasu. Krakow: Polskie Wydawnictwo Muzyczne, 1976.

Boreiko, Tymish [Klyment Kvitka]. "Narodni spivtsi-profesionaly." [Folk Singers-professionals.”] Ridnyi krai 15 (1912): 15-19. [Борейко, Тиміш (Климент Квітка). “Народні співці-професіонали." Рідний край 15 (1912): 15-19.]

Demuc'kij, Porfirij. Narodni ukrainski pisni v Kyjivshbyni zapysav golos i slova P. Demuc'kyj. [Ukrainian Folk Songs in Kyiv Region Recorded the Voices and Words of P. Demutskyi.] Kiev: Gl. Sklad v kn. i muz. magazin Leona Idzikovskago, 1905. [Демуцький, Порфирий. Народни украински писни въ Кыйивщыни запысав голосъ и слова П. Демуиькый. Киевъ Гл. Складъ въ кн. и муз.магазинъ Леона Идзиковскаго, 1905.]

Franko, Ivan. Vybrani statti pro narodnu tvorchist. [Selected Articles on Folk Art.] Kyiv: Vydvo Akademii nauk URSR, 1955. [Франко, Іван. Вибрані статті про народну творчість. Київ: вид-во Академії наук УРСР, 1955.]

Halytsko-ruski narodni melodii. Zibrav na fonohraf Y. Rozdolskyi, spysav i zredahuvav S. Liudkevych. Vol. 1. [Galician-Rus Folk Melodies. Collected with a phonograph by O. Rozdolskyi, written and edited by S. Lyudkevych.] Etnohrafichnyi zbirnyk Naukovoho tovarystva im. Shevchenka. Vol. 21. Lviv, 1906. [Галицько-руські народні мелодіï. Зібрав на фонограф Й. Роздольський, списав і зредагував С. Людкевич. Етнографічний збірник Наукового товариства ім. Шевченка. Т. ХХІ. Львів, Ч. 1, 1906.]

Halytsko-ruski narodni melodii. Zibrav na fonohraf Y. Rozdolskyi, spysav i zredahuvav S. Liudkevych. Vol. 2. [Galician-Rus Folk Melodies. Collected with a phonograph by O. Rozdolskyi, written and edited by S. Lyudkevych.] Etnohrafichnyi zbirnyk Naukovoho tovarystva im. Shevchenka. Vol. 22. Lviv, 1908. [Галицько-руські народні мелодіï. Зібрав на фонограф Й. Роздольський, списав і зредагував С. Людкевич. Етнографічний збірник Наукового товариства ім. Шевченка. Т. ХХІІ. Львів, Ч. 2, 1908.]

Hornbostel, Erich Moritz. "Die Probleme der Vergleichenden Musikwissenschaft." Zeitschrift der Internationalen Musikgesellschaft 7 (1905): 85-97.

Kolessa, Filaret. "Starynni melodii ukrainskykh obriadovykh pisen (vesilnykh i koliadok) na Zakarpatti." In F. M. Kolessa: Muzykoznavchi pratsi, 368-397 ["Ancient Melodies of Ukrainian Ritual Songs (Weddings and Carols) in Transcarpathia.” In F. M. Kolessa: Musicological Works.] Kyiv: Naukova dumka, 1970. [Колесса, Філарет. "Старинні мелодії українських обрядових пісень (весільних і колядок) на Закарпатті.” Ф. М. Колесса: Музикознавчі прачі, 368-397. Київ: Наукова думка, 1970.]

Kolessa, Filaret. "Rytmika ukrainskykh narodnykh pisen." In F. M. Kolessa: Muzykoznavchi pratsi, 21-233 ["Rhythmics of Ukrainian Folk Songs." In F. M. Kolessa: Musicological Works.] Kyiv: Naukova dumka, 1970. [Колесса, Філарет. "Ритміка українських народних пісень.” Ф. М. Колесса: Музикознавчі праці, 21-233. Київ: Наукова думка, 1970.]

Kvitka, Klyment. Zbirnyk ukrainskykh pisen z notamy. [Collection of Ukrainian Songs with Melodies.] Kyiv, 1902, $1^{\text {st }}$ ed. [Квітка, Климент. Збірник українських пісень з нотами. Київ, Вип. 1, 1902.]

Kvitka, Klyment. Narodni melodii z holosu Lesi Ukrainky (Melodii z tekstom ta prymitkamy). [Folk Melodies from the Voice of Lesya Ukrainka (Melodies with Text and Notes).] Zapysav i uporiadyv [z peredm.] Klyment Kvitka, Vol. 1-2. Kyiv: [Vydannia avtora], 1917-1918. [Квітка, Климент. Народні мелодї з голосу Лесі Украӥнки (Мелодї з текстом 
mа примітками). Ч. 1-2. Записав і упорядив [з передм.] Климент Квітка. Київ: [Видання автора], 1917-1918.]

Kvitka, Klyment. "Ukrainskie pesni o materi-detoubijce." In Kvitka K. Izbrannye trudy v dvuh tomah, 119-191. ["Ukrainian Songs about the Mother Child-killer." In Kvitka K: Selected Works in Two Volumes.] Moskva: Soviet kompozitor, Vol. 2. 1973. [Квитка, Климент. "Украинские песни о матери-детоубийце" Квитка К. Избранные труды в двух томах, Vol. 2, 119-191. Сост. и коммент. В. Л. Гошовского. Москва: Советский композитор, 1973.]

Lukaniuk, Bohdan. "Kulturo-zhanrova kontseptsiia S. Liudkevycha." In Chetverta konferentsiia doslidnykiv narodnoi muzyky chervonoruskykh (halytsko-volodymyrskykb) ta sumizhnykh zemel: Materialy, 7-14. ["Cultural-genre Concept of S. Lyudkevych." In Fourth Conference of Researchers of Folk Music of the Red Rus (Galician-Volodymyr) and Adjacent Lands: Materials.] Lviv, 1993. [Луканюк, Богдан. "Культуро-жанрова концепція С. Людкевича: До постановки питання." Четверта конференція дослідників народної музики червоноруських (галицько-володимирських) та суміжних земель: Матеріали, 7-14. Упорядник Б. Луканюк. Львів, 1993.]

Lukaniuk, Bohdan. "Stanislav Liudkevych yak zachynatel typolohichnoi shkoly v ukrainskomu etnomuzykoznavstvi." In Zbirnyk statei $i$ materialiv v pamiat Yaremy Yakubia$k a$ (1942-2002), 140-161 ["Stanislav Lyudkevych as the Founder of the Typological School in Ukrainian Ethnomusicology." In Collection of Articles and Materials in Memory of Yarema Yakubyak (1942-2002).] Uporiadnyk M. Kushnir. Lviv: Kameniar, 2007. [Луканюк, Богдан. Станіслав Людкевич як зачинатель типологічної школи в українському етномузикознавстві. Збірник статей і матеріалів в пам'ять Яреми Якубяка (1942-2002), 140-161. Упорядник М. Кушнір. Львів: Каменяр, 2007.]

Liudkevych, Stanyslav. "Muzyka sertsia." In Ivan Franko u spohadakh suchasnykiv, 175-177. ["Music of the Heart." In Ivan Franko in the Memoirs of Contemporaries.] Book 2, ordering, preface and notes O. Deia. Lviv: Kameniar, 1972. [Людкевич, Станіслав. Музика серця. Іван Франко у спогадах сучасників. Книга 2, упорядкування, передмова та примітки О. Дея, 175-177. Львів: Каменяр, 1972.]

Pavlyshyn, Stefaniia. Stanislav Liudkerych. [Stanyslav Lyudkevych.] Kyiv: Muzychna Ukraina, 1974. [Павлишин, Стефанія. Станіслав Людкевич. Київ: Музична Україна, 1974.]

Potebnia, Oleksandr. Poiasnennia malorosiiskykh i sporidnenykh narodnykh pisen: Koliadky ta shchedrivky. [Explanation of Little Russian and Related Folk Songs: Carols and Shchedrivkas.] Vol. 2. Varshava: Drukarnia Mykhaila Zemkevicha, 1887. [Потебня, Олександр. Пояснення малоросійських і споріднених народних пісень: Колядки та щедрівки. Частина 2. Варшава: Друкарня Михайла Земкевіча, 1887.]

Shtunder, Zenoviia. Liudkerych S.: Doslidzhennia, statti, retsenzii, vystupy. [Lyudkerych S.: Research, Articles, Revierws, Speeches.] Vol. 1. Lviv: Dyvosvit, 1999. [Штундер, Зеновія. Людкевич С.: Дослідження статті, рецензї, виступи. Т. 1. Львів: Дивосвіт, 1999.]

Shtunder, Zenoviia. Liudkerych S.: Doslidzhennia, statti, retsenzii, vystupy. [Lyudkevych S.: Research, Articles, Reviews, Speeches.] Vol. 2. Lviv: Dyvosvit, 2000. [Штундер, Зеновія. Людкевич С.: Дослідження, статті, рецензї, виступи. Т. 2. Львів: Дивосвіт, 2000.]

Shtunder, Zenoviia. Stanislav Liudkevych: Zhyttia i tvorchist. Vol. 1 (1879-1939). [Stanyslav Lyudkevych. Life and Work. Vol. 1 (1879-1939).] Lviv: BINAR-2000, 2005. [Штундер, Зеновія. Станіслав Людкевич: Життя і творчість. Т. 1 (1879-1939). Львів: ПП БIHAP-2000, 2005.] 
Shtunder, Zenoviia. Stanislav Liudkevych: Zhyttia i tvorchist. Vol. 2 (1939-1979). [Stanyslav Lyudkerych. Life and Work. Vol. 2 (1939-1979).] Lviv-Zhovkva: Misioner, 2009. [Штундер, Зеновія. Станіслав Людкевич: Життя і творчість. Т. 2 (1939-1979). Львів-Жовква: Місіонер, 2009.]

Sokalskyi, Petro. Ruska narodna muzyka: rosiiska i ukrainska v yii budovi melodychnii i rytmichnii vidminnosti yii vid osnov suchasnoi harmonichnoi muzyky. [Rus Folk Music: Russian and Ukrainian in its Melodic Structure and Rhythmic Difference from the Foundations of Modern Harmonic Music.] Kyiv: Derzhavne vydavnytstvo obrazotvorchoho mystetstva i muzychnoi literatury URSR, 1959. [Сокальський, Петро. Руська народна музика: російська і українська в ї̈ будові мелодичній і ритмічній відмінності ії від основ сучасної гармонічної музики. Київ: Державне видавництво образотворчого мистецтва і музичної літератури УРСР, 1959.]

Ukrainski narodni melodii. Zibrav Klyment Kvitka. [Ukrainian Folk Melodies. Collected by Klyment Kvitka.] Kyiv: Slovo, 1922. [Українські народні мелодї. Зібрав Климент Квітка. Київ: Слово, 1922.]

Ukrainka, Lesia. Zapysy narodnoi tvorchosti: Pisni, zapysani z holosu Lesi Ukrainky. [Records of Folk Art: Songs Recorded from the Voice of Lesya Ukrainka.] Vol. 9, ordering and notes by O. I. Deia and S. Y. Hrytsy; vol. ed. F. P. Pohrebennyk, 11-98. Kуiv, 1977. [Українка, Леся. Записи народної творчості: Пісні, записані з голосу Лесі Украӥнки, 11-98. Т. 9, упорядкування та примітки О. І. Дея і С. Й. Грици; редактор тому Ф. П. Погребенник. Київ, 1977.]

Wallaschek, Richard. Anfänge der Tonkunst. Leipzig: J. A. Barth, 1903.

Zahaikevych, Mariia. S. P. Liudkevych: Narys pro zhyttia i tvorchist. [Stanyslav Ludkevych. Essay on Life and Work.] Kyiv: Derzhavne vydavnytstvo obrazotvorchoho mystetstva i muzychnoi literatury URSR, 1957. [Загайкевич, Марія. С. П. Людкевич. Нарис про життя i творчість. Київ: Державне видавництво образотворчого мистецтва і музичної літератури УРСР, 1957.] 


\section{POVZETEK}

\section{Prispevek Stanislava Ljudkijeviča k zgodovini raziskovanja ukrajinske ljudske glasbe na začetku 20. stoletja}

Stanislav Ljudkijevič je kot utemeljitelj primerjalne muzikologije v zgodovini ukrajinske glasbene folklore podrobno analiziral zbirko Halytsko-ruski narodni melodii (Galicijsko-ruske narodne pesmi) in jo strukturno in tipološko opredelil. Omenjena zbirka vključuje 1525 melodij, zabeleženih v zahodni Ukrajini: od območja reke Zbruč do zahodnega dela Karpatov. Delo je pomembno kot dragocen dodatek $\mathrm{k}$ folklornim zbirkam iz srednje in vzhodne Ukrajine. S. Ljudkijevič je gradivo v zbirki sistematiziral glede na žanre, pri čemer je bil glavni poudarek na razvrščanju pesmi po ritmičnih značilnostih verzov in kitic.

Stanislav Ljudkijevič se ukvarja s konceptualnimi pristopi k ritmični strukturi ukrajinskih ljudskih pesmi in s koncepti prozodije in melodičnega ritma, ki so nekaj posebnega in označujejo narečno specifičnost melodije. $\mathrm{Na}$ osnovi načel sistematizacije in klasifikacije glasbene folklore v zbirki Halytsko-ruski narodni melodii je bilo zbrano glasbeno in folklorno gradivo znanstveno utemeljeno. Strukturno-tipološko načelo razvrščanja se je izkazalo za učinkovito in pripomoglo $\mathrm{k}$ razumevanju narave strukturiranja ljudske pesmi in njenega multivariantnega izvora.

Dodaten poudarek je na kulturni in žanrski sistematizaciji ukrajinske glasbene folklore, ki jo je zasnoval Stanislav Ljudkijevič. Osnovo za določanje oblike pesmi predstavljata njeni najpomembnejši značilnosti - ritmična struktura pesmi in shematični ritmični vzorec melodije, ki ju v določenih primerih dopolnjujejo posebnosti tonske strukture. Kulturno-žanrska sistematizacija folklore je prispevala $\mathrm{k}$ radikalnim spremembam glede na žanr in vrsto, kar je omogočilo novo klasifikacijo ukrajinske folklore.

\section{ABOUT THE AUTORS}

OLEG S. SMOLIAK (smolyak.te@gmail.com) is a professor at the department of Musicology and Methodology of Musical Art, Doctor of Art Studies (DA) of the Ternopil Volodymyr Hnatiuk National Pedagogical University (Ternopil, Ukraine). He is a researcher in the field of musicology and folklore, teacher, conductor, member of the National Union of Composers of Ukraine, he is a winner of the regional cultural award in 2016 in the category "Ethnography and Museology - named after Volodymyr Hnatyuk." He is an author of numerous scientific and methodological publications, educational programs in ethnography, music folklore. He is a compiler, editor and publisher of collections of folk songs and works by Ukrainian composers.

ANATOLIY M. BANKOVSKYI (1958anaban@gmail.com) is an Associate Professor at the department of Musicology and Methodology of Musical Art of the Ternopil Volodymyr Hnatiuk National Pedagogical University and Honored Art Worker of Ukraine (Ternopil, Ukraine). His creative output includes about 200 arrangements of musical songs and works. $\mathrm{He}$ is an author of about 25 scientific articles and educational manuals on pedagogical and music education, as well as author of dance music, arranger and performer.

OKSANA Z. DOVHAN (dovhan.violino@i.ua) is an Associate Professor at the department of Musicology and Methodology of Musical Art of the Ternopil Volodymyr Hnatiuk 
National Pedagogical University, she is also a candidate of Pedagogical Sciences (Ternopil, Ukraine). She is a teacher of the history of Ukrainian music and solfeggio and an author of about twenty scientific and scientific-methodical works on the history of violin art, pedagogy and musical folklore, educational programs and methodical recommendations. Her research interests include the history of music and the work of Galician composers in the first half of the twentieth century.

HALYNA S. MISKO (ogaleksis@ukr.net) is an Assistant at the department of Musicology and Methodology of Musical Art of the Ternopil Volodymyr Hnatiuk National Pedagogical University (Ternopil, Ukraine). Her research activities are aimed at studying the state of Christmas rituals in Western Podillya from the mid-seventeenth century to the present day. She is an author and compiler of the collection "Carols of Western Podillya." She has published more than thirty publications, including methodological developments, programs, articles, published in professional journals and in the materials of scientific conferences of various levels.

NATALIA M. OVOD (ovodnatalya583@gmail.com) is an Assistant at the department of Musicology and Methodology of Musical Art of the Ternopil Volodymyr Hnatiuk National Pedagogical University and Honored Art Worker of Ukraine (Ternopil, Ukraine). Her research interests are aimed at history and development of vocal creativity of Ukrainian singers from the mid-twentieth century to the present day. She also studies the interaction of creative relations between representatives of Lviv and Kyiv Schools of Composers. She is an author of scientific articles, vocal and conducting educational programs and methodical recommendations.

\section{O AVTORJIH}

OLEG S. SMOLIAK (smolyak.te@gmail.com) je profesor na Oddelku za muzikologijo in metodologijo glasbene umetnosti, doktoriral je iz umetnostnih ved na Nacionalni pedagoški univerzi Volodimirja Hnatjuka v Ternopilu (Ternopil, Ukrajina). Je raziskovalec na področju muzikologije in folklore, učitelj, dirigent, član Nacionalne zveze skladateljev, je prejemnik regionalne kulturne nagrade za leto $2016 \mathrm{v}$ kategoriji »Etnografija in muzeologija - poimenovana po Volodimirju Hnatjuku«. Je avtor številnih znanstvenih in metodoloških publikacij, izobraževalnih programov s področja etnografije, glasbene folklore in ukrajinske glasbene ustvarjalnosti za šole, glasbene šole in univerze.Je zbiratelj, urednik in izdajatelj zbirk ljudskih pesmi in del ukrajinskih skladateljev.

ANATOLIJ M. BANKOVSKI (1958anaban@gmail.com) je izredni profesor na Oddelku za muzikologijo in metodologijo glasbene umetnosti na Nacionalni pedagoški univerzi Volodimirja Hnatjuka v Ternopilu in častni umetnik Ukrajine (Ternopil, Ukrajina). Njegov ustvarjalni opus zajema približno 200 priredb pesmi in skladb, poleg tega je tudi avtor plesne glasbe, aranžer in performer. Je avtor približno 25 znanstvenih člankov in izobraževalnih priročnikov o pedagoški in glasbeni izobrazbi.

OKSANA Z.DOVHAN (dovhan.violino@i.ua) je izredna profesorica na Oddelku za muzikologijo in metodologijo glasbene umetnosti na Nacionalni pedagoški univerzi Volodimirja Hnatjuka v Ternopilu in kandidatka pedagoških znanosti (Ternopil, Ukrajina). Je učiteljica 
zgodovine ukrajinske glasbe in solféggia ter avtorica približno dvajsetih znanstvenih in znanstveno-metodičnih del o zgodovini violinske umetnosti, pedagogike in glasbene folklore, izobraževalnih programih in metodoloških priporočilih. Raziskovalno se posveča zgodovini glasbe in delu galicijskih skladateljev v prvi polovici 20. stoletja.

HALINA S. MISKO (ogaleksis@ukr.net) je asistentka na Oddelku za muzikologijo in metodologijo glasbene umetnosti Nacionalne pedagoške univerze Volodimirja Hnatjuka v Ternopilu, Ukrajina. Težišče njenega raziskovanja so božični obredi v Zahodni Podoliji od sredine 17. stoletja do danes. Je avtorica in urednica zbirke Božične pesmi iz Zahodne Podolije (Carols of Western Podilya). Objavila je več kot trideset publikacij, vključno z metodološkimi koncepti, programi, članki, ki so bili objavljeni v strokovnih revijah in gradivih znanstvenih konferenc.

NATALIJA M. OVOD (ovodnatalya583@gmail.com) je asistentka na Oddelku za muzikologijo in metodologijo glasbene umetnosti Nacionalne pedagoške univerze Volodimirja Hnatjuka v Ternopilu, Ukrajina. Njena interesna področja so: zgodovina in razvoj vokalne ustvarjalnosti pri ukrajinskih pevcih in pevkah od 2. polovice 20. stoletja do danes. Preučuje ustvarjalno interakcijo med predstavniki lvovske in kijevske skladateljske šole. Je avtorica znanstvenih člankov, vokalnih in dirigentskih izobraževalnih programov ter metodoloških priporočil. 